\title{
WHAT I HAVE LEARNED FROM PROFESSOR PEDRO PAULO FUNARI
}

Monica Selvatici ${ }^{1}$

"Give me two lemons and I will make you lemonade". This saying is the first thing that comes to my mind when I think of Professor Pedro Paulo Funari. I heard him repeat it several times when I was following my PhD studies in Cultural History at Campinas State University (UNICAMP) from 2002 to 2006. Funari was, then, the co-advisor to my dissertation, along with André Chevitarese. ${ }^{2}$

Funari's pragmatism towards academic life, added to a significant amount of optimism and resilience, made him strong when facing academy's vicissitudes like grant cuts, student scholarship cuts, or occasional animosity among faculty members. "Give me two lemons and I will make you lemonade". When FAPESP made scholarship granting a more difficult process, turning down any request, we students were not supposed to give up trying: "let's write a recourse explaining the importance of the present research work!". And, so, many of those initial negative responses turned eventually into grant awards. As a man of few complaints and with a lot of initiative, he would always highlight both in lectures and in books the progress of Brazilian scholarship in Ancient History.

Professor Funari is a voracious reader and writer. His long résumé is his trade mark, and we, students, have learned to admire it and to make it a goal of ours (obviously not reachable), when building our own academic career. With regard to that, he has definitely helped us and still does by way of the many publication opportunities he has given us in Boletim do Centro do Pensamento Antigo and in books he edited.

In the PhD courses I took at UNICAMP there was a lot of reading into Post-modern authors, who questioned in multiple ways History's

\footnotetext{
${ }^{1}$ Associate Professor, Londrina State University, Londrina, Brazil. E-mail: mselvatici@gmail.com

${ }^{2}$ I am very thankful to professor Funari for the excellent tip he gave me, at the beginning of my research on the Hellenists in the book of Acts, about approaching the subject by way of identity studies and the concept of ethnicity. This precious tip rendered originality to my dissertation analysis.
} 
scientific nature. Although I have already resolved in my mind the issue of History as science - it is, of course, science for it has methods and theories, but a peculiar kind of science that incorporates subjectivity - the "sting" of relativism, so visible among post-moderns, has left its mark in me. There is no perfect theory, no finished debate on any subject whatsoever. There are theoretical choices, pertinent as they are from their own perspective.

More than that, I learned while at UNICAMP how to historicize scholarship's scientific interpretive frameworks. Funari himself noted already in 1999 that, in European scholarly panorama, scholars had been finding it necessary to historicize "both scientific interpretive frameworks and the 'invention' of evidence in order to find new evidence and the 'creative power' for understanding it" (1999: 42). In fact, he was greatly responsible for introducing this procedure among Brazilian Antiquity researchers from 2000 on, accounted the numerous books, MA theses and PhD dissertations (mine included) from his advisees that have adopted the method of historicizing scientific interpretive frameworks when analyzing various aspects of the ancient world.

It is necessary to contextualize every scholar's ideas... I practice this exercise in my academic life; I try hard to teach it to my students (who arrive at university so "knowing it all"!); and I make an effort to do the same in my personal life. I have learned this important lesson from Professor Pedro Paulo Funari.

\section{Reference}

FUNARI, Pedro P.A. Historical archaeology from a world perspective. In: FUNARI, P.P.A.; HALL, M.; JONES, S. (Org.) Historical Archaeology. Back from the Edge. London and New York: Routledge, 1999, p. 37-66. 